\title{
Streamlining the use of legislated reporting to move to 'life of project' sustainability reporting
}

$\operatorname{AUTHOR}(\mathrm{S})$ :

McLellan, B.C.

\section{CITATION:}

McLellan, B.C.. Streamlining the use of legislated reporting to move to 'life of project' sustainability reporting. International Journal of Mining and Mineral Engineering 2014, 5(1): 19-37

\section{ISSUE DATE:}

2014

URL:

http://hdl.handle.net/2433/199588

\section{RIGHT:}

(c) 2014 Inderscience Enterprises Ltd.; この論文は出版社版でありませ ん。引用の際には出版社版をご確認ご利用ください。; This is not the published version. Please cite only the published version. 


\title{
Streamlining the use of legislated reporting to move to "Life of project" sustainability reporting
}

McLellan, B.C. ${ }^{1}$

University of Queensland, Sustainable Minerals Institute, Centre for Social Responsibility in Mining, St Lucia, Queensland 4072, Australia.

\begin{abstract}
The minerals industry has made extensive efforts in sustainable development, and reporting of sustainability performance has been increasing. This paper examines the current role of legislated reporting, and the ways in which it can help streamline sustainability reporting, saving time and money. Two sets of sustainability metrics - the global reporting initiative (GRI) and the Institution of Chemical Engineers (IChemE) - are examined to demonstrate the coverage of sustainability reporting by legislated reporting. The paper also proposes the shifting of perspective from "life of mine" to "life of project" sustainability reporting. Greater use of legislated activities such as environmental impact assessments is described as a way of creating more useful, relevant and realistic sustainability reports. Through the use of these early phase activities to develop contextualised sustainability metrics, the sustainability contribution of a project can be more effectively measured across the life cycle and currently under-utilised information can be used more fully.
\end{abstract}

Keywords: sustainability; reporting; metrics; minerals; environmental regulation;

\section{Introduction}

Sustainability and sustainable development (SD) have become key words in the minerals industry especially since the significant global activities of the early $21^{\text {st }}$ century - forming the ICMM (International Council on Mining and Metals) and undertaking the MMSD (Mining and Minerals in Sustainable Development) project (IIED and WBCSD 2002). Consequently, sustainability reporting has been an area of increasing interest and activity in the minerals industry, as evidenced by the numerous corporate sustainability reports. While currently voluntary in most jurisdictions,

\footnotetext{
${ }^{1}$ Author current address and contact details: Postal Address:

Graduate School of Energy Science, Kyoto University, Yoshida-honmachi, Sakyo-ku, Kyoto 606-8501, Japan.

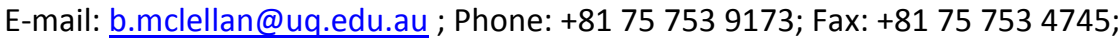


This is a pre-print version of the paper: McLellan, B. (2014). "Streamlining the use of legislated reporting to move to 'life of project' sustainability reporting." International Journal of Mining and Mineral Engineering 5(1): 19-37. DOI: 10.1504/IJMME.2014.058917

sustainability reporting is additional to, and may often duplicate, legislated reporting requirements, adding to the reporting burden of already busy operations. There is thus an apparent opportunity for streamlining the development and reporting of sustainability metrics to reduce duplication, highlight improvement opportunities and ensure sufficient coverage of key impact areas. In addition to streamlining reporting requirements, there is an opportunity to improve the value of this activity, through the incorporation of baseline data from other required activities such as Environmental Impact Assessment (EIA) which is largely under-utilised at present.

Streamlining and validating sustainability reporting may facilitate and increase its take-up, as a comparison of legislated versus voluntary reporting for Australia (for example) indicates that only a relatively small fraction of the companies and facilities that must legally report on their environmental emissions (over 550 in the minerals industry in 2009) (NPI 2010) are reporting voluntarily using the Global Reporting Initiative (GRI) (GRI 2006) framework (estimated at $15-20 \%$ coverage in 2009) (Lee and Park 2005). (The GRI is the most widely applied, pseudo-standard reporting framework and is therefore used here for illustration however, the Institution of Chemical Engineers (IChemE) sustainability metrics (IChemE, Azapagic et al. 2003) which is also compared here, or other similar metrics systems - e.g. (Veleva and Ellenbecker 2001; Azapagic 2004) - could also be applied.)

There has been some interest in recent years in the integration of various environmental techniques and routine reporting activities with environmental improvement strategies (Tan and Khoo 2005; Xiao-wu, Li-rong et al. 2008; Humbert, Loerincik et al. 2009; Kofoworola and Gheewala 2009). Examinations of the use of pollutant release and transfer register reporting as a basis for identifying and initially assessing opportunities for cleaner production (Neto, Kroeze et al. 2008) have been undertaken. Methods for deriving eco-efficiency indicators from environmental management accounting applications (Rebitzer and Buxmann) have been demonstrated and there it has also been suggested that preference should be given to legislated or existing reporting (as a source of data) when deriving sustainability or corporate social responsibility indicators for businesses (O'Connor and Spangenberg 2008), especially when the collation of such data can be challenging in many cases (Du, Han et al. 2010). However, the connections have not been specifically identified between current legislated reporting and sustainability indicators.

The literature indicates that current legislation in different countries and industries has been successful to some degree in the pollution prevention, but that alternate methods (including voluntary reporting schemes) may be useful in improving environmental performance beyond compliance (Ermolaeva, Castro et al. 2004; Tharumarajah and Koltun 2007; Blackett, Savory et al. 2008; Du, Han et al. 2010). It has further been identified that the effective co-ordination of voluntary and regulated schemes may lead to greater improvement for sustainable development (Gao, Nie et al. 2008).

The primary argument of this paper is that there exists a significant wealth of data currently being reported under legislation that can be used to streamline the reporting of sustainability metrics. Additionally, there is a need to incorporate the results of other legislated activities - in particular the pre-construction phase environmental impact assessment (EIA) and social impact assessment (SIA), which can make sustainability metrics more contextually relevant. This could be termed a move from "Life of Mine" sustainability reporting to "Life of Project" sustainability reporting. 
This is a pre-print version of the paper: McLellan, B. (2014). "Streamlining the use of legislated reporting to move to 'life of project' sustainability reporting." International Journal of Mining and Mineral Engineering 5(1): 19-37. DOI: 10.1504/IJMME.2014.058917

\section{Methodology}

The fundamental hypothesis of this paper is that there is already a significant amount of legislated reporting that occurs, both from the corporate and the operational level of industry, much of which can either facilitate the sustainability reporting process, or be used to add greater meaning to standard sustainability reports. In order to examine this hypothesis, three steps were followed:

1. A structured review of industry sustainability-related (environmental, social and financial) legislated reporting within Australia (as one of the largest minerals producing countries)

2. Systematic comparison of legislated reporting requirements and the requirements of major sustainability reporting frameworks (GRI and IChemE) to identify cross-over and areas that could be improved to enhance the relevance, comprehensibility and value of sustainability reporting.

3. Examination of a number of sustainability reports from the minerals industry to identify (where possible) whether the use of legislated reporting was being made directly, and particularly the extent to which contextual information that has already been reported in regulatory processes could be further employed in sustainability reports.

The discussion section of this paper then discusses a number of key areas for improvement found in the process of this examination and an ongoing review and monitoring of the literature in regards to sustainability assessment and reporting within the minerals industry ( $\mathrm{M}^{\prime}$ Lellan 2007; McLellan, Corder et al. 2009; Corder, McLellan et al. 2012).

\section{Overview of Legislated Reporting}

Legislated reporting schemes vary from between countries and states in regards to coverage, timing and extent of oversight. This section reviews legislated reporting requirements in the minerals industry that could reasonably be considered to have some cross-over with sustainability reporting. To be considered relevant, this legislated reporting was required to indicate coverage of at least one aspect of the triple bottom line (TBL).

The legislated reporting framework in Australia is used in this paper to demonstrate the possibilities that are presently available to improve and enhance sustainability reporting. This will not be reflective of all jurisdictions, but it is expected that most developed countries will have parallel frameworks and that rapidly developing countries will soon look to implement similar structures. Furthermore, most of the largest international mining companies operate in Australia (with some having key bases there) and thus they are required to report under this legislation. Moreover, many of these international mining companies are committed to the highest level of environmental and social practices, regardless of their country of operation. In this way, Australia could be said to represent "good practice" in reporting. A further consideration is that the level of regulated reporting varies depending on the size, structure, intensity and productivity of a given business or operation. The reporting schemes examined in this paper generally relate to larger businesses, as Small to Medium Enterprises (SME's) may not reach the thresholds for regulated reporting. SME's cannot be neglected in their importance for sustainable development (both as a source of local benefit as well as their impacts) (Cherubini, Raugei et al. 2008) however, it has been identified that voluntary sustainability reporting is less likely to be undertaken by smaller businesses due to 
This is a pre-print version of the paper: McLellan, B. (2014). "Streamlining the use of legislated reporting to move to 'life of project' sustainability reporting." International Journal of Mining and Mineral Engineering 5(1): 19-37. DOI: 10.1504/IJMME.2014.058917

capacity constraints and legislative pressure (Tharumarajah and Koltun 2007; Cherubini, Raugei et al. 2008; Fuchs, Field et al. 2008).

In regards to the triple bottom line of sustainability, current major Australian legislated reporting is indicated in Figure 1. The areas of reporting most relevant to sustainability performance monitoring on the environmental bottom line are considered to be:

- $\quad$ National Pollutant Inventory (NPI) 2 - industrial operations are required to report their emissions of 93 substances if these emissions surpass a minimum annual threshold

- National Greenhouse and Energy Register (NGER) ${ }^{3}$ - industrial operations emitting greenhouse gases above the relevant facility level or corporate level threshold must report

- $\quad$ Energy Efficiency Opportunities (EEO) 4 - high energy use operations or businesses must complete an energy audit and examine opportunities for improving energy efficiency

They are also required to monitor and record the following within their Environmental Management Plan (EMP) (DERM 2009):

- waste flows, types, destinations and volumes

- (and report) information about spills

- and, to rehabilitate land within 6 months of completion of activity.

Environmental Impact Statement (EIS) or EIA processes are also currently mandated for significant industrial developments (DIP 2007). The social bottom line contribution of current reporting is derived from the Social Management Plan (SMP) and SIA component of EIA (DIP 2010). However, these elements of reporting have only recently been legislated, hence there are many operations that have not been required to undertake such assessments. It is apparent from the literature around the application of Environmental Impact Assessment (EIA) that there is significant room for improvement in the process and utilisation of the outcomes of EIA, which is perhaps the most significant and resource-intensive of legislated reporting activities (McKillop and Brown 1999; Ridgway 1999; Ramakrishnan and Koltun 2004; Kofoworola and Gheewala 2009).

Finally, financial reporting is a requirement for large businesses in Australia (FWA 2009), and provides an initial basis for the economic bottom line. Standard business accounting is also a source of key data on internal corporate financial sustainability, as well as identifying any direct flows of money to support local community activities.

In addition, it is recognised that the current reporting of sustainability aspects can also occur as additional elements of Annual Reports that companies produce (Al Mutaz and Wagialia 1990; Blackett, Savory et al. 2008) or as Environmental and / or Social Reports (Hägg 2001; Berlik, Kittredge et al. 2002). This is sometimes a voluntary inclusion and sometimes regulated. There has however,

\footnotetext{
${ }^{2}$ www.npi.gov.au

${ }^{3} \mathrm{http} / / / \mathrm{www}$. climatechange.gov.au/government/initiatives/national-greenhouse-energy-reporting.aspx

${ }^{4}$ http://www.ret.gov.au/energy/efficiency/eeo/pages/default.aspx
} 
This is a pre-print version of the paper: McLellan, B. (2014). "Streamlining the use of legislated reporting to move to 'life of project' sustainability reporting." International Journal of Mining and Mineral Engineering 5(1): 19-37. DOI: 10.1504/IJMME.2014.058917

been a reported trend towards more use of the GRI indicators and more stand-alone sustainability reports (Berlik, Kittredge et al. 2002).

From an examination of the GRI indicators and the current reporting requirements (see Appendix A) it can be seen that legislated reporting can account for most of the indicators in the "Environmental" and "Economic" categories of the GRI framework. So from the perspective of these categories, it is relatively straightforward to streamline the development of sustainability indicators by simply reproducing legislated reporting. "Society", "Labor practices and decent work", "Human rights" and "Product responsibility" are categories which would require further internal research and calculation - no doubt the information is there however there is no legal requirement to report it explicitly. The qualitative nature of information in these categories can also means that they are less reliant on data and more on policy (Hutchins and Sutherland 2008). Of particular note is the fact that the GRI's "Society" category does not correlate well with the aims and content of typical SIA's or SMP's. The IChemE's sustainability performance metrics (IChemE, Azapagic et al. 2003) match somewhat more closely to the available data in the legislated reporting (see Appendix B). Therefore these metrics could be achieved more readily and with minimal additional work over and above current reporting. Perhaps the reason for this closer match is the industrial facility focus of the IChemE as opposed to the more general and corporate focus of the GRI.

Figure 1 indicates the phase of development of a project at which these legislated processes are active, and the scope of the Global Reporting Initiative (GRI 2006) sustainability metrics as a comparison. It can be observed that the majority of reporting processes are focussed on the operational phase of a project. This is neither unexpected, nor unreasonable, given that the majority of impacts of the project would be expected at this phase and that apart from the closure phase this is typically the longest phase in the life cycle of a project.

$<$ Figure 1>

One element that is not shown in Figure 1 is the direction of focus of this reporting. Most legislated reporting is internally focussed (the system boundary is drawn around the company or operation) whereas in sustainability reporting, the focus must also account for the host community and environment as a minimum (the system boundary incorporates the community and environment to extent of the company's influence).

EIA for example, is focussed on the surrounding host environment and community of the operation, and what effects may arise from its implementation. However, once an EIA is accepted by the regulators and an EMP is initiated, the activity enters a phase of largely internal focus - i.e. environmental impact is considered largely in terms of emissions, and reduction of emissions is in term considered an onsite monitoring and improvement activity. Ongoing reporting to regulators can enable trends in progress to be established, but unlike the holistic concept of sustainability which requires a conception of the operation as a connected entity within its host environment and community, it allows the operation and its manufactured capital to be considered independently and in isolation. The flows of energy, matter, money and information that connect the organisation or operation to its surroundings are not considered (in current reporting) to be dynamic carriers of "sustainability potential" but rather, as static, line item figures. 
This is a pre-print version of the paper: McLellan, B. (2014). "Streamlining the use of legislated reporting to move to 'life of project' sustainability reporting." International Journal of Mining and Mineral Engineering 5(1): 19-37. DOI: 10.1504/IJMME.2014.058917

\section{Examination of current practice in Sustainability Reporting}

In order to clarify whether and to what extent the incorporation of data and information has occurred in sustainability reports by mining companies, a number of available reports online were examined. Many companies' sustainability reporting is on a group or corporate level - often without breakdown of data on an operation-by-operation basis (e.g. BHP Billiton (2010)) - in such cases these reports were not able to be compared readily. From the remaining sustainability reports for minerals companies operating in Australia, seven reports out of those which were on a site / operation level or group level with breakdown of data were examined - covering a number of medium to large minerals companies (as shown in Table 1 ).

The examination of the reports first attempted to identify whether NPI, NGERS and EEO were referenced and / or utilised in the derivation or reporting of data. In regards to NPI data, 3 referenced the NPI and did not show any data in the SD report, while another 3 referred to the NPI and showed a subset of summary data, while one report did not reference the NPI. This indicates a varied, but generally positive adoption of legislated reporting data directly into the SD report. NGERS reports are at a company-wide level, and although mentioned in many of the SD reports, the breakdown is not available for comparison. Although mentioned in most, the EEO reported opportunities were only described in detail in one SD report.

The next step was to examine whether the environmental management system (EMS) or the EMP was mentioned, and whether there was any data taken from or related to the EIA for the operation. In most cases, the EMS / EMP was mentioned - but mostly as an indication that an overall environmental policy or plan was in place (not quoted as a direct source of information - and not identified as providing contextual information). In many cases, the EMP is a requirement of the EIA process, but for some operations this was not legislated at the time of commissioning. Due to the delay between when the EIA was accepted and when the current SD report was examined, the original EIA for the operations was unavailable for examination and comparison (and although attempts were made to find operations currently reporting with available recent EIAs, this was unsuccessful). However, some related documents - e.g. the EIS assessment report for the Curragh North mine associated with the Wesfarmers Curragh operation (QEPA 2004), the McArthur River Mine Open Cut EIS (URS 2005) and the government responses to both the original EIA (NTEPU 1992) and the Open Cut EIS (NTEPA 2006) (project not approved, but data still relevant). To summarise, it is apparent that although significant environmental studies have been undertaken, little of this has been incorporated into the sustainability report. For example, consideration of the limitations on water withdrawal from underground aquifers was modelled and acceptable levels agreed to, but these are not used for comparison with the current withdraw.

Perhaps the best examples of incorporation of EIA-related data into sustainability reporting, the air quality management model of Mount Isa Mines described in the Xstrata Zinc sustainability report (Xstrata Zinc 2011) and the "Lead pathways study" described in the Mount Isa Mines sustainability report (Mount Isa Mines 2011). Mount Isa Mines was not required to undertake an EIA when it began operating - long before such environmental legislation was enacted. However, due to its high emissions of sulphur dioxide and concerns about Lead levels in the community, and the close 
This is a pre-print version of the paper: McLellan, B. (2014). "Streamlining the use of legislated reporting to move to 'life of project' sustainability reporting." International Journal of Mining and Mineral Engineering 5(1): 19-37. DOI: 10.1504/IJMME.2014.058917

proximity of the operations to the community, it is the subject of significant efforts for reduction of emissions. The consideration of sustainability ultimately requires consideration of the critical thresholds for such emissions - these are considered in the setting of legislative limits for concentration and emission, and are a key focus in the EIA process where atmospheric and hydrological modelling are carried out at length to determine potential for impact and avoidance. By incorporating emissions modelling as a prevention tool and reporting on actual ground-level concentrations compared with legislated and health limits, Mount Isa Mines' sustainability reporting moves closer to reporting actual sustainability performance - rather than merely measuring relative to previous performance (this is discussed further in Section 5.2). 
Word count $=$

Table 1: Selected sustainability reports

\begin{tabular}{|c|c|c|c|c|c|c|c|}
\hline Company & Reference & Level & NGERS & EEO & $\mathrm{NPI}$ & EMP / EMS & EIA / EIS \\
\hline $\begin{array}{l}\text { Wesfarmers } \\
\text { Resources }\end{array}$ & $\begin{array}{l}\text { (Wesfarmers } \\
\text { Resources 2011) }\end{array}$ & $\begin{array}{l}\text { Two operations + } \\
\text { corporate office }\end{array}$ & $\begin{array}{l}\text { Not mentioned- } \\
\text { although parent } \\
\text { company reports }\end{array}$ & $\begin{array}{l}\text { Referred to for reportable } \\
\text { energy efficiency } \\
\text { opportunities (no data in SD } \\
\text { report) }\end{array}$ & $\begin{array}{l}\text { Referred to for } \\
\text { reportable emissions } \\
\text { details (no data in SD } \\
\text { report) }\end{array}$ & Mentioned & $\begin{array}{l}\text { Not mentioned - } \\
\text { Curragh North EIS } \\
\text { recently approved; }\end{array}$ \\
\hline Panoramic & $\begin{array}{l}\text { (Panoramic } \\
\text { Resources 2011) }\end{array}$ & $\begin{array}{l}\text { Corporate (multi- } \\
\text { operation) }\end{array}$ & Mentioned & $\begin{array}{l}\text { Referred to for reportable } \\
\text { energy efficiency } \\
\text { opportunities (no data in SD } \\
\text { report) }\end{array}$ & $\begin{array}{l}\text { Referred to for } \\
\text { reportable emissions } \\
\text { details (no data in SD } \\
\text { report) }\end{array}$ & Mentioned & - \\
\hline Xstrata Zinc & $\begin{array}{l}\text { (Xstrata Zinc } \\
\text { 2011) }\end{array}$ & $\begin{array}{l}\text { Group (multi- } \\
\text { operation) }\end{array}$ & $\begin{array}{l}\text { Mentioned } \\
\text { (NGERS data at } \\
\text { Xstrata Holdings } \\
\text { corporate level } \\
\text { only) }\end{array}$ & $\begin{array}{l}\text { Referred to for reportable } \\
\text { energy efficiency } \\
\text { opportunities (no data in SD } \\
\text { report) }\end{array}$ & $\begin{array}{l}\text { Referenced; Summary } \\
\text { data on } 2 \text { substances in } \\
\text { SD report; } \\
\text { Data not matched to } \\
\text { NPI due to different } \\
\text { aggregation level }\end{array}$ & $\begin{array}{l}\text { Mentioned - new } \\
\text { plan not yet } \\
\text { implemented }\end{array}$ & $\begin{array}{l}\text { Air Quality } \\
\text { Management Model - } \\
\text { parallel to EIA; }\end{array}$ \\
\hline Xstrata-MIM & $\begin{array}{l}\text { (Mount Isa } \\
\text { Mines 2011) }\end{array}$ & $\begin{array}{l}\text { Multiple associated } \\
\text { operations }\end{array}$ & $\begin{array}{l}\text { Mentioned } \\
\text { (NGERS data at } \\
\text { Xstrata Holdings } \\
\text { corporate level } \\
\text { only) }\end{array}$ & $\begin{array}{l}\text { Referred to for reportable } \\
\text { energy efficiency } \\
\text { opportunities (no data in SD } \\
\text { report) }\end{array}$ & $\begin{array}{l}\text { Referenced; Summary } \\
\text { data on } 8 \text { substances in } \\
\text { SD report; } \\
\text { Data matches NPI }\end{array}$ & Mentioned & - \\
\hline $\begin{array}{l}\text { Xstrata - } \\
\text { MacArthur River } \\
\text { Mine }\end{array}$ & $\begin{array}{l}\text { (McArthur River } \\
\text { Mining 2009) }\end{array}$ & Single operation & $\begin{array}{l}\text { Mentioned } \\
\text { (NGERS data at } \\
\text { Xstrata Holdings } \\
\text { corporate level } \\
\text { only) } \\
\end{array}$ & Not mentioned & $\begin{array}{l}\text { Referred to for } \\
\text { reportable emissions } \\
\text { details (no data in SD } \\
\text { report) }\end{array}$ & $\begin{array}{l}\text { Mentioned (Mine } \\
\text { management plan) }\end{array}$ & \\
\hline $\begin{array}{l}\text { Rio Tinto - } \\
\text { Northparkes }\end{array}$ & (Rio Tinto 2011) & Single operation & $\begin{array}{l}\text { Mentioned } \\
\text { (NGERS data at Rio } \\
\text { Tinto corporate } \\
\text { level only) }\end{array}$ & $\begin{array}{l}\text { Mentioned (and detail on } \\
\text { improvements } \\
\text { implemented) }\end{array}$ & $\begin{array}{l}\text { Not mentioned; } \\
\text { SD report and NPI data } \\
\text { differ }\end{array}$ & Not mentioned & - \\
\hline OZ Minerals & $\begin{array}{l}\text { (OZ Minerals } \\
\text { 2011) }\end{array}$ & $\begin{array}{l}\text { Single operation }+ \\
\text { corporate office }+ \\
\text { exploration }\end{array}$ & $\begin{array}{l}\text { Mentioned } \\
\text { SD report and } \\
\text { NGERS data differ } \\
\text { slightly }\end{array}$ & $\begin{array}{l}\text { Mentioned (but not yet } \\
\text { complete) }\end{array}$ & $\begin{array}{l}\text { Mentioned / } \\
\text { referenced; } \\
\text { Summary data on } 5 \\
\text { substances in SD } \\
\text { report; } \\
\text { Data matches NPI }\end{array}$ & Mentioned & - \\
\hline
\end{tabular}


Word count $=$

\section{Discussion}

Having reviewed literature, legislation and industry sustainability reporting, a number of areas of potential improvement or extended application of legislated reporting in deriving sustainability reports that reflect the project life cycle are discussed. Legislated reporting as a source of sustainability indicators and relevant reporting data, adding value to reporting through improved context from the EIA and the role of reporting in innovation are examined hereafter.

\subsection{Legislated reporting helping to derive sustainability indicators}

There is an ongoing discussion in the literature about the benefits of a prescribed set of sustainability metrics (top-down (Schor 2005) or technocratic approach) versus the derivation of indicators that match the particular needs of a specific operation, application or location (bottom-up approach) (Yokoyama and lji 1995; Shields, Solar et al. 2002; Spangenberg 2002; Arena, Mastellone et al. 2003; Schor 2005; Harding, Dennis et al. 2007; Rametsteiner, Pülzl et al. 2011) or combinations of the two (Spangenberg 2002; Pope, Annandale et al. 2004). If we view this from the perspective of legislated processes that are already undertaken we can see the potential to make a closer-fitting and more meaningful set of indicators that embrace either approach.

Specifically focussing on EIA and SIA, which have often been criticised as ineffectual in their ultimate outcomes (McKillop and Brown 1999), there is found to be a (largely) wasted opportunity to engage in sustainability indicator development. The mandated processes for EIA and SIA typically involve periods of consultation with local stakeholders - both to help determine community concerns and priorities, and for comment on the draft EIA / SIA documents (DIP 2007; DIP 2010). Likewise, the bottom-up development of sustainability indicators for communities, cities and regions involves a similar (though typically broader) process (Hodge 2004; Harding, Dennis et al. 2007). Although individual projects or operations may not be able to cover the full scope of concerns that a community may have, by utilising this legislated consultation process as at least a starting point, sustainability indicators and goals can be developed to monitor performance against community expectation. This process should also assist the company in gaining a "social license to operate".

In addition, the top-down approach to sustainability indicator development can also be aided by such consultation. If a prescribed set of indicators (or at least a set of headline indicators) is used as the starting point for discussions, then the consultation processes involved in the EIA/SIA can be used in similar fashion to separate the key issues for the community from the issues of less concern.

The scientific or analytical elements of EIA / SIA can be used in similar fashion. An EIA process in particular, is required to identify major areas of potential impact of the proposed operation or project. The level of impact that the operation is expected to have on the different indicators can be used to highlight those indicators which should be monitored regularly and those which will require less focus. Applying EIA / SIA with the consideration of future sustainability reporting in mind can therefore offer the potential to reduce some degree of "double counting" and associated costs. 
This is a pre-print version of the paper: McLellan, B. (2014). "Streamlining the use of legislated reporting to move to 'life of project' sustainability reporting." International Journal of Mining and Mineral Engineering 5(1): 19-37. DOI: 10.1504/IJMME.2014.058917

The use of EIA / SIA to assist in contextualising the sustainability report also leads to the potential to shift the consideration of sustainability from a "life of mine" to a "life of project" framework. If we consider the reporting across the life cycle of the project (Figure 1), we can see that the majority of the focus of reporting is in the operation phase. However, sustainability reporting is concerned with a longer time frame - stretching from the pre-construction phase through long into closure. Currently, EIA / SIA processes are used almost exclusively to gain approval for a project. If the process of determining appropriate sustainability metrics, and the baselining for the project were undertaken simultaneously at this pre-construction phase, flowing seamlessly on into the operational phases, then the wealth of information that is currently lost (aside from contributions that enter the EMP / SMP), would instead be carried-over. The following section describes some of the key developments that could be implemented under this changed paradigm.

\subsection{Adding value to sustainability reporting}

Legislated reporting can be used not only to provide data and indicators for sustainability reporting, but also to add value to sustainability reports. One particular area is in the determination of critical loads, thresholds and carrying capacities for the local environment / community. This is the "sustainability context" which is largely missing in current sustainability reporting (McElroy, Jorna et al. 2008) but is a key part of EIA / SIA processes.

Sustainability may be considered as a state of dynamic equilibrium in which the tension between an operation and its surrounding environment, community and economy is of paramount importance. The contribution of an operation to the total load or pressure on the environment, in conjunction with its contribution to improved social and economic conditions is a defining aspect of sustainability, and the magnitude of impacts and benefits should also take into account the available carrying capacity of the specific location in which it is situated (Jin and High 2004; Ramakrishnan and Koltun 2004; Diniz da Costa and Pagan 2006; McLellan 2007; McElroy, Jorna et al. 2008). In other words, a relationship between the indicators of environmental condition and operational performance should be created (Perugini, Mastellone et al. 2005). EIA in particular typically involves the use of extensive hydrological and atmospheric modelling, as well as the examination of scenarios of usage and impact. While the results of such modelling are of variable accuracy, it still represents an attempt to quantify location-specific carrying capacity limitations and areas of high impact. Although some of this data is carried-over into the EMP, most of it is not, and that which is carried-over becomes an implicit part of the monitoring schemes rather than an explicit benchmark or threshold.

"Binary-oriented" (McElroy, Jorna et al. 2008) indicators, which include such carrying capacity measures explicitly are not often utilised in sustainability reporting, but could increase the usefulness of sustainability reports significantly. For example, GRI indicator EN20 (GRI 2006) reports the emissions of Nitrogen and Sulphur Oxides and other significant air emissions by type and weight. In an EIA process, the atmospheric transport and deposition of these emissions will typically have been carried out and health or environmental regulations applied to ensure concentrations below required levels. However, these limits can also be incorporated in the sustainability indicator, to identify how far from unsustainable the operation is (McLellan 2007; McElroy, Jorna et al. 2008). By "back-casting" from the level of emissions that exceed critical thresholds at the site of impact to the corresponding source emissions level at the operation, modelling from the EIA can provide the threshold of sustainability that can be incorporated in the binary-oriented indicator. 
This is a pre-print version of the paper: McLellan, B. (2014). "Streamlining the use of legislated reporting to move to 'life of project' sustainability reporting." International Journal of Mining and Mineral Engineering 5(1): 19-37. DOI: 10.1504/IJMME.2014.058917

To illustrate: if the absolute emissions of a contaminant at the operation (source) is currently $90 \mathrm{t}$ / $\mathrm{hr}$, but modelling indicates that $100 \mathrm{t} / \mathrm{hr}$ is sufficient to exceed threshold levels, then the binary indicator may be given by $90 / 100=90 \%$ of the sustainability limit. If on the other hand, emissions were $120 \mathrm{t} / \mathrm{hr}$, then the indicator would be $120 \%$ of the sustainability limit (McElroy, Jorna et al. 2008).

One of the key reasons necessitating such a binary approach is that current indicators of sustainability, without incorporation of carrying capacity, can mask or not alert the user when an activity is coming close to the threshold of unsustainability. For example, the change in emissions in the previous example would currently be noticed in terms of standard performance indicators, but the risks associated with this $33 \%$ increase in emissions may not be seen as significant. This would be particularly hidden if the increase in emissions happened to be associated with, say, a 50\% increase in production, as often indicators are given on a normalised basis per tonne of output.

It must be said that current monitoring requirements may identify such issues in a timely fashion but if sustainability reporting is undertaken, then increasing the relevance of such reporting would seem to be appropriate. Furthermore, the cumulative effects of subsequent industrial development, better scientific understanding or legislative change must also be considered, and updates applied to modelling results as needed. The derivation of carrying capacities or goal states from social management plans could also be undertaken using slight adjustments to the methodology.

\subsection{Reporting, innovation and regulation}

While focusing on reporting to identify progress towards sustainability, it is also important to consider where this reporting falls within the bigger picture of the development, operation and eventual closure of an industrial operation, and what can and cannot be achieved through reporting.

As indicated in Figure 1, the majority of reporting activities (legislated and voluntary) occur during the operational phase of a project. However, once an operation has reached this phase, much of the potential for change for greater sustainable development contribution is no longer available (Corder, McLellan et al. 2010). The case of EIA processes is one which particularly highlights this issue, as EIA's require assessment of alternatives to the proposed design, but are typically only undertaken once projects have at least entered pre-feasibility, and the most significant alternatives are no longer being considered in design (Corder, McLellan et al. 2010). The switch to a "life of project" approach to reporting may contribute somewhat to remedying this - just as the earlier integration of sustainability principles can produce large potential improvements in contributing to sustainable development (Corder, McLellan et al. 2012).

Reporting, if fed back into a continuous improvement process, can become useful data to prompt and develop innovative new solutions to improve sustainability performance (Finnveden, Johansson et al. 2005; Neto, Kroeze et al. 2008), for example, looking at waste reuse opportunities for spin-off enterprise development (Kurdikar, Fournet et al. 2000). However, under current conditions this is not typically the case. Rather, with the focus of reporting on merely performing against regulatory limits, there is minimal drive to produce innovative solutions that involve a holistic, sustainability perspective (Kurdikar, Fournet et al. 2000; McLellan and Corder 2011). 
This is a pre-print version of the paper: McLellan, B. (2014). "Streamlining the use of legislated reporting to move to 'life of project' sustainability reporting." International Journal of Mining and Mineral Engineering 5(1): 19-37. DOI: 10.1504/IJMME.2014.058917

\section{Conclusions}

It is apparent that on at least the economic and environmental categories of sustainability reporting, there is significant overlap with current legislated reporting. This overlap indicates potential for regulatory reporting to streamline the provision of data for sustainability reporting. There are however, some gaps - notably from the GRI metrics in the areas of "Society", "Labor practices", "Human rights" and "Product responsibility" which cannot simply be covered by current legislated reporting. The IChemE's sustainability metrics, which focus mostly on industrial facilities, are more adequately covered by current reporting than the GRI.

Furthermore, there is information produced for pre-construction phase legislated activities such as EIA / SIA's that is currently not being carried over into the sustainability reports as "sustainability context", but only incorporated into the environmental / social management plans. Better utilisation of this information can help to produce "binary indicators" for sustainability reporting that include carrying capacity and give indication of whether sustainability thresholds are in danger of being breached.

The development of indicators themselves - whether by selection from a predefined set such as the GRI's, or through a consultative process to match the specific needs and priorities of a given community - can be integrated into or complement the EIA / SIA consultation process. If undertaken early enough in the design process, this can be the prompt for innovation to obtain holistic sustainability-based solutions to improve operational performance.

Indicator development at the early stages of a project, when so much useful information and modelling is produced, could change the focus and value of sustainability reporting to enhancing sustainable development rather than just reporting. This "life of project" approach is proposed as an advance on the current "life of mine" sustainability reporting.

Altogether, the impact of these approaches would be expected to result in higher quality, more relevant sustainability reporting. Cost and time resources required for the combined activities of legislated and sustainability reporting could also be expected to be reduced.

\section{Acknowledgements}

The research and writing for this paper was able to be undertaken due to internal funding granted by the Sustainable Minerals Institute of the University of Queensland. The author acknowledges and appreciates this contribution.

\section{References}

Al Mutaz, I. S. and K. M. Wagialia (1990). "Production of magnesium from desalination brines." Resources, Conservation and Recycling 3(4): 231-239.

Arena, U., M. Mastellone, et al. (2003). "Life Cycle assessment of a plastic packaging recycling system." The International Journal of Life Cycle Assessment 8(2): 92-98.

Azapagic, A. (2004). "Developing a framework for sustainable development indicators for the mining and minerals industry." Journal of Cleaner Production 12(6): 639-662. 
This is a pre-print version of the paper: McLellan, B. (2014). "Streamlining the use of legislated reporting to move to 'life of project' sustainability reporting." International Journal of Mining and Mineral Engineering 5(1): 19-37. DOI: 10.1504/IJMME.2014.058917

Berlik, M. M., D. B. Kittredge, et al. (2002). "The illusion of preservation: a global environmental argument for the local production of natural resources." Journal of Biogeography 29(10-11): 1557-1568.

BHP Billiton (2010). 2010 BHP Billiton Sustainability Report. Melbourne, BHP Billiton: 54.

Blackett, G., E. Savory, et al. (2008). "An evaluation of the environmental burdens of present and alternative materials used for electricity transmission." Building and Environment 43(7): 1326-1338.

Cherubini, F., M. Raugei, et al. (2008). "LCA of magnesium production: Technological overview and worldwide estimation of environmental burdens." Resources, Conservation and Recycling 52(8-9): 1093-1100.

Corder, G. D., B. C. McLellan, et al. (2012). "Engineering-in sustainability through the application of SUSOP ${ }^{\circledR}$." Chemical Engineering Research and Design 90(1): 98-109.

Corder, G. D., B. C. McLellan, et al. (2010). "Incorporating sustainable development principles into minerals processing design and operation: SUSOP ${ }^{\circledR}$." Minerals Engineering 23(3): 175-181.

DERM (2009). Code of environmental compliance for certain aspects of extractive and screening activities (ERA 16). Q. G. Department of Environment and Resource Management. Brisbane, Queensland Government.

Diniz da Costa, J. C. and R. J. Pagan (2006). "Sustainability Metrics for Coal Power Generation in Australia." Trans IChemE, Part B 84(B1): 1-7.

DIP (2007). Guidelines for environmental impact statements under the Integrated Planning Act 1997. Q. G. Department of infrastructure and Planning. Brisbane, Queensland Government.

DIP (2010). Social Impact Assessment - preparing a social impact management plan: draft guideline. Q. G. Department of infrastructure and Planning. Brisbane, Queensland Government.

Du, J., W. Han, et al. (2010). "Life cycle greenhouse gases, energy and cost assessment of automobiles using magnesium from Chinese Pidgeon process." Journal of Cleaner Production 18(2): 112-119.

Du, J. D., W. J. Han, et al. (2010). "Potential for reducing GHG emissions and energy consumption from implementing the aluminum intensive vehicle fleet in China." Energy 35(12): 4671-4678.

Ermolaeva, N. S., M. B. G. Castro, et al. (2004). "Materials selection for an automotive structure by integrating structural optimization with environmental impact assessment." Materials \& Design 25(8): 689-698.

Finnveden, G., J. Johansson, et al. (2005). "Life cycle assessment of energy from solid waste--part 1: general methodology and results." Journal of Cleaner Production 13(3): 213-229.

Fuchs, E. R. H., F. R. Field, et al. (2008). "Strategic materials selection in the automobile body: Economic opportunities for polymer composite design." Composites Science and Technology 68(9): 1989-2002.

FWA (2009). Financial reporting guidelines (s253). F. W. Australia. Canberra, Australian Government.

Gao, F., Z.-r. Nie, et al. (2008). "Assessing environmental impact of magnesium production using Pidgeon process in China." Transactions of Nonferrous Metals Society of China 18(3): 749754.

GRI (2006). Sustainability Reporting Guidelines. GRI. Amsterdam, Netherlands, Global Reporting Initiative.

Hägg, M.-B. (2001). "Purification of chlorine gas with membranes -- an integrated process solution for magnesium production." Separation and Purification Technology 21(3): 261-278.

Harding, K. G., J. S. Dennis, et al. (2007). "Environmental analysis of plastic production processes: Comparing petroleum-based polypropylene and polyethylene with biologically-based poly[beta]-hydroxybutyric acid using life cycle analysis." Journal of Biotechnology 130(1): 57-66.

Hodge, R. A. (2004). "Mining's seven questions to sustainability: from mitigating impacts to encouraging contribution." Episodes 27(3): 177-184. 
This is a pre-print version of the paper: McLellan, B. (2014). "Streamlining the use of legislated reporting to move to 'life of project' sustainability reporting." International Journal of Mining and Mineral Engineering 5(1): 19-37. DOI: 10.1504/IJMME.2014.058917

Humbert, S., Y. Loerincik, et al. (2009). "Life cycle assessment of spray dried soluble coffee and comparison with alternatives (drip filter and capsule espresso)." Journal of Cleaner Production 17(15): 1351-1358.

Hutchins, M. J. and J. W. Sutherland (2008). "An exploration of measures of social sustainability and their application to supply chain decisions." Journal of Cleaner Production 16(15): 1688-1698.

IChemE, A. Azapagic, et al. (2003). The Sustainability Metrics - Sustainable Development Progress Metrics. Rugby, UK, Institution of Chemical Engineers.

IIED and WBCSD (2002). Breaking new ground: Mining, minerals and sustainable development. Mining Minerals and Sustainable Development Project, International Institute for Environment and Development and World Business Council for Sustainable Development.

Jin, X. and K. A. High (2004). Comparative vs. Absolute Performance Assessment with Environmental Sustainability Metrics. 2004 AIChE Annual Meeting, Austin, Texas, USA, American Institution of Chemical Engineers.

Kofoworola, O. F. and S. H. Gheewala (2009). "Life cycle energy assessment of a typical office building in Thailand." Energy and Buildings 41(10): 1076-1083.

Kurdikar, D., L. Fournet, et al. (2000). "Greenhouse Gas Profile of a Plastic Material Derived from a Genetically Modified Plant." Journal of Industrial Ecology 4(3): 107-122.

Lee, K.-M. and P.-J. Park (2005). "Estimation of the environmental credit for the recycling of granulated blast furnace slag based on LCA." Resources, Conservation and Recycling 44(2): 139-151.

McArthur River Mining (2009). Xstrata McArthur River Mining Sustainability Report 2008. Brisbane, Australia, Xstrata Holdings: 38.

McElroy, M. W., R. J. Jorna, et al. (2008). "Sustainability Quotients and the Social Footprint." Corporate Social Responsibility and Environmental Management 15: 223-234.

McKillop, J. and A. L. Brown (1999). "Linking Project Appraisal and Development: The Performance of EIA in Large-Scale Mining Projects." Journal of Environmental Assessment Policy \& Management 1(4): 407.

McLellan, B. (2007). PhD Thesis: Location-Specific Sustainability Metrics for Hydrogen Energy Systems, University of Queensland.

McLellan, B. C. and G. D. Corder (2011). Designing-in Sustainability in Industrial Projects and Processes. EcoDesign 2011 - 7th International Symposium on Environmentally Conscious Design and Inverse Manufacturing, Kyoto, Japan, Springer.

McLellan, B. C., G. D. Corder, et al. (2009). "Incorporating sustainable development in the design of mineral processing operations - Review and analysis of current approaches." Journal of Cleaner Production 17(16): 1414-1425.

Mount Isa Mines (2011). Xstrata Mount Isa Mines Sustainability Report 2010. Brisbane, Australia, Xstrata Holdings: 52.

Neto, B., C. Kroeze, et al. (2008). "Modelling the environmental impact of an aluminium pressure die casting plant and options for control." Environmental Modelling \& Software 23(2): 147-168.

NPI. (2010). "National Pollutant Inventory Emissions Data 2009-10." Retrieved August 15th, 2010, from www.npi.gov.au.

NTEPA (2006). McArthur River Mine Open Cut Project - Environmental Assessment Report. Darwin, Environmental Protection Agency of the Northern Territory Government: 51.

NTEPU (1992). McArthur River Project - Proposed Zinc-Lead-Silver Mine - Environmental Assessment Report and Recommendations. Darwin, Environmental protection unit of the conservation commission of the Northern Territory: 85.

O'Connor, M. and J. H. Spangenberg (2008). "A methodology for CSR reporting: assuring a representative diversity of indicators across stakeholders, scales, sites and performance issues." Journal of Cleaner Production 16(13): 1399-1415.

OZ Minerals (2011). OZ Minerals Sustainability Report 2010. Melbourne, Victoria, OZ Minerals Ltd: 43. 
This is a pre-print version of the paper: McLellan, B. (2014). "Streamlining the use of legislated reporting to move to 'life of project' sustainability reporting." International Journal of Mining and Mineral Engineering 5(1): 19-37. DOI: 10.1504/IJMME.2014.058917

Panoramic Resources (2011). Sustainability Report 2010. Perth, Western Australia, Panoramic Resources Ltd: 53.

Perugini, F., M. L. Mastellone, et al. (2005). "A life cycle assessment of mechanical and feedstock recycling options for management of plastic packaging wastes." Environmental Progress 24(2): 137-154.

Pope, J., D. Annandale, et al. (2004). "Conceptualising sustainability assessment." Environmental Impact Assessment Review 24(6): 595-616.

QEPA (2004). EIS Assessment Report - Curragh North Coal Project - Bowen Basin, Central Queensland. Brisbane, Queensland Environmental Protection Agency: 20.

Ramakrishnan, S. and P. Koltun (2004). "Global warming impact of the magnesium produced in China using the Pidgeon process." Resources, Conservation and Recycling 42(1): 49-64.

Rametsteiner, E., H. Pülzl, et al. (2011). "Sustainability indicator development--Science or political negotiation?" Ecological Indicators 11(1): 61-70.

Rebitzer, G. and K. Buxmann "The role and implementation of LCA within life cycle management at Alcan." Journal of Cleaner Production 13(13-14): 1327-1335.

Ridgway, B. (1999). "The Project Cycle and the Role of EIA and EMS." Journal of Environmental Assessment Policy \& Management 1(4): 393.

Rio Tinto (2011). Northparkes mines Sustainable Development Report 2010. Melbourne, Victoria, Rio Tinto Ltd: 57.

Schor, J. B. (2005). "Prices and quantities: Unsustainable consumption and the global economy." Ecological Economics 55(3): 309-320.

Shields, D. J., S. V. Solar, et al. (2002). "The role of values and objectives in communicating indicators of sustainability." Ecological Indicators 2(1-2): 149-160.

Spangenberg, J. H. (2002). "Environmental space and the prism of sustainability: frameworks for indicators measuring sustainable development." Ecological Indicators 2(3): 295-309.

Tan, R. B. H. and H. H. Khoo (2005). "An LCA study of a primary aluminum supply chain." Journal of Cleaner Production 13(6): 607-618.

Tharumarajah, A. and P. Koltun (2007). "Is there an environmental advantage of using magnesium components for light-weighting cars?" Journal of Cleaner Production 15(11-12): 1007-1013.

URS (2005). McArthur River Mine open cut project - Draft Environmental Impact Statement. Brisbane, Australia, Xstrata Holdings.

Veleva, V. and M. Ellenbecker (2001). "Indicators of sustainable production: framework and methodology." Journal of Cleaner Production 9(6): 519-549.

Wesfarmers Resources (2011). Sustainability Report 2010. Brisbane, Queensland, Wesfarmers Resources Ltd: 56.

Xiao-wu, W., G. Li-rong, et al. (2008). "Resources conservation--The alternative scenarios for Chinese aluminum industry." Resources, Conservation and Recycling 52(10): 1216-1220.

Xstrata Zinc (2011). Xstrata Zinc Australia Sustainability Report 2010. Brisbane, Australia, Xstrata Holdings: 50.

Yokoyama, S. and M. Iji (1995). Recycling of thermosetting plastic waste from electronic component production processes. Electronics and the Environment, 1995. ISEE., Proceedings of the 1995 IEEE International Symposium on. 
This is a pre-print version of the paper: McLellan, B. (2014). "Streamlining the use of legislated reporting to move to 'life of project' sustainability reporting." International Journal of Mining and Mineral Engineering 5(1): 19-37. DOI: 10.1504/IJMME.2014.058917

\section{Figure Captions}

Figure 1: Sustainability-related processes and reporting schemes across project phases and the triple bottom line

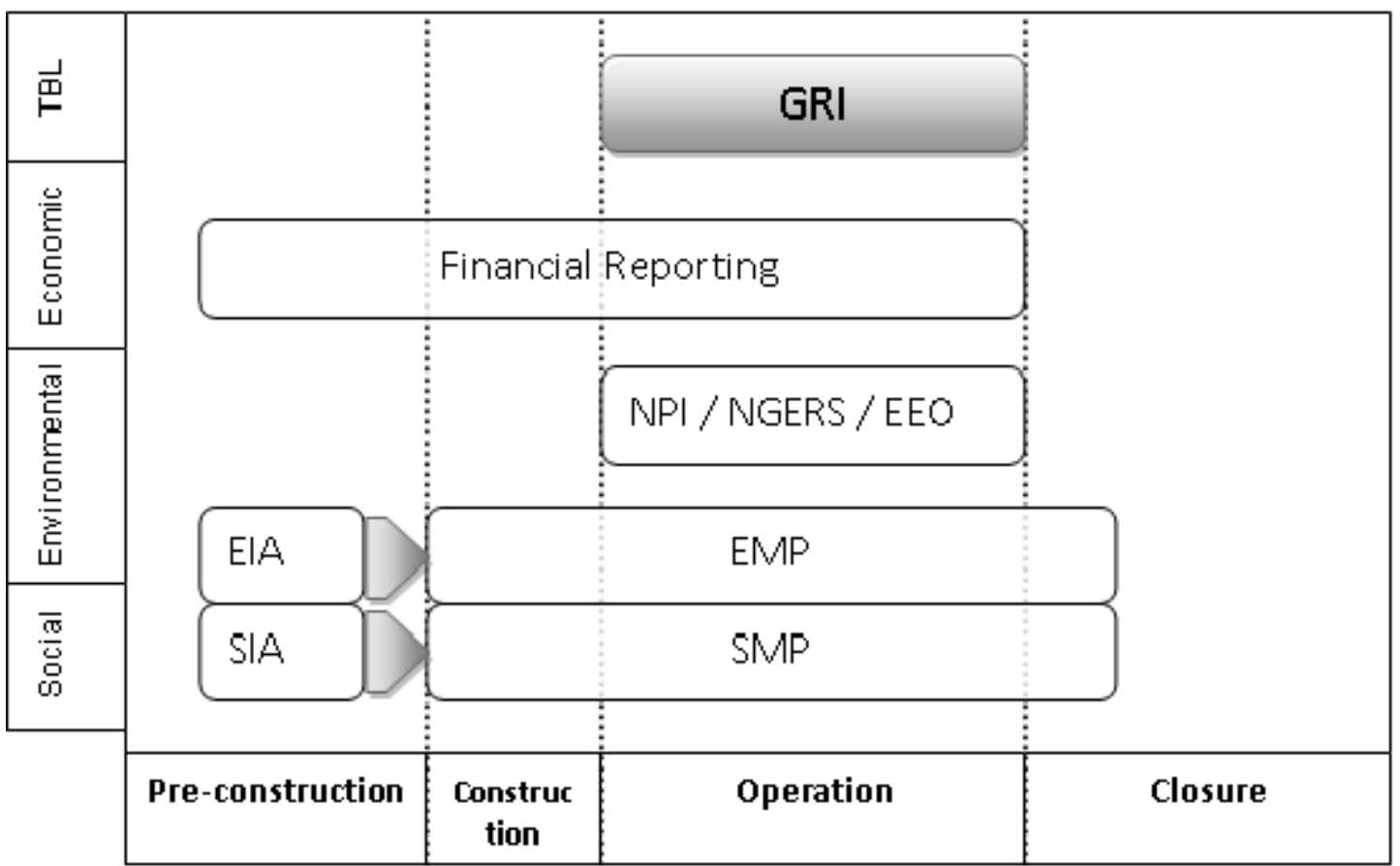




\section{Appendix A}

\section{Identification of current coverage of Global Reporting Initiative sustainability metrics under legislated reporting}

The following table lists the identified coverage of GRI sustainability metrics under current (Australian) legislated reporting.

\section{Abbreviations:}

$A R$ - Annual report (can often substitute for annual financial report)

EEO - Energy Efficiency Opportunities

EIA - Environmental Impact Assessment

EMP - Environmental Management Plan

FR - Financial Reporting

NGER - National Greenhouse Emissions Register

NIBT - Net income before tax

NPI - National Pollutant Inventory

SIA - Social Impact Assessment (or social component of EIA in some cases)

SMP - Social Management Plan

(?) - not explicitly required to be reported under current legislation 
This is a pre-print version of the paper: McLellan, B. (2014). "Streamlining the use of legislated reporting to move to 'life of project' sustainability reporting." International Journal of Mining and Mineral Engineering 5(1): 19-37. DOI: 10.1504/IJMME.2014.058917

\begin{tabular}{|c|c|c|}
\hline GRI category & GRI Indicators & LR Source \\
\hline \multirow[t]{3}{*}{ Economic } & EC1 - EC4 & $\mathrm{FR}$ \\
\hline & EC5 & (?) \\
\hline & EC6-EC9 & SMP \\
\hline \multirow[t]{6}{*}{ Environmental } & EN19-20 & NPI \\
\hline & EN5-7 & EEO \\
\hline & EN3-4, EN16-18 & NGERS \\
\hline & EN1,EN8-12,EN14-15, EN25 & EIA \\
\hline & EN10, EN13, EN22-24, EN30 & EMP \\
\hline & EN2, EN21, EN26-29 & (?) \\
\hline Labor practices and decent work & LA1-14 & (?) \\
\hline Human rights & HR1-9 & (?) \\
\hline \multirow[t]{2}{*}{ Society } & SO1 & SMP / Closure Plan \\
\hline & SO2-9 & (?) \\
\hline Product responsibility & PR1-9 & (?) \\
\hline
\end{tabular}




\section{Appendix B}

\section{Identification of current coverage of Institution of Chemical Engineers' sustainability metrics under legislated reporting}

The following tables list the identified coverage of IChemE sustainability metrics under current (Australian) legislated reporting.

\begin{tabular}{|c|c|c|}
\hline $\begin{array}{l}\text { Environmental indicator } \\
\text { categories }\end{array}$ & Indicators & LR Source \\
\hline \multicolumn{3}{|l|}{ Resource usage } \\
\hline \multirow[t]{4}{*}{$\begin{array}{r}\text { Energy } \\
\text { (By fuel, primary and final } \\
\text { energy) }\end{array}$} & $\begin{array}{l}\text { Total Net Primary Energy Usage rate }=\text { Imports - } \\
\text { Exports }\end{array}$ & EEO \\
\hline & $\begin{array}{l}\text { Percentage Total Net Primary Energy sourced from } \\
\text { renewable }\end{array}$ & EEO \\
\hline & Total Net Primary Energy Usage per kg product & EEO \\
\hline & Total Net Primary Energy Usage per unit value added & EEO \\
\hline \multirow[t]{9}{*}{$\begin{array}{r}\text { Material (excluding fuel and } \\
\text { water) }\end{array}$} & Total raw materials used, including packaging & EIA /EMP (?) \\
\hline & Raw material recycled from other company operations & EIA /EMP(?) \\
\hline & Raw material recycled from consumer & $\begin{array}{l}\text { EIA / EMP } \\
\text { (?) }\end{array}$ \\
\hline & $\begin{array}{l}\text { Raw material used which poses health, safety or } \\
\text { environmental hazard }\end{array}$ & EIA / EMP \\
\hline & Total raw materials used per kg product & EIA / EMP \\
\hline & Total raw materials used per unit value added & $\begin{array}{l}\text { EIA / EMP / } \\
\text { FR }\end{array}$ \\
\hline & Fraction of raw materials recycled within company & EIA / EMP \\
\hline & Fraction of raw materials recycled from consumers & EIA / EMP \\
\hline & Hazardous raw material per kg product & EIA / EMP \\
\hline \multirow[t]{2}{*}{ Water } & Net water consumed per unit mass of product & EIA / EMP \\
\hline & Net water consumed per unit value added & $\begin{array}{l}\text { EIA / EMP / } \\
\text { FR }\end{array}$ \\
\hline \multirow[t]{2}{*}{ Land } & Total land occupied + affected for value added & EIA / EMP \\
\hline & Rate of land restoration (restored per year /total) & EIA / EMP \\
\hline \multirow[t]{3}{*}{ Emissions, effluents and waste } & Atmospheric impacts & NPI / NGER \\
\hline & Aquatic impacts & NPI \\
\hline & Impacts to land & NPI \\
\hline $\begin{array}{l}\text { Additional environmental } \\
\text { items }\end{array}$ & & \\
\hline
\end{tabular}


This is a pre-print version of the paper: McLellan, B. (2014). "Streamlining the use of legislated reporting to move to 'life of project' sustainability reporting." International Journal of Mining and Mineral Engineering 5(1): 19-37. DOI: 10.1504/IJMME.2014.058917

\begin{tabular}{|l|l|l|}
\hline Economic indicator categories & Indicators & LR Source \\
\hline Profit, value and tax & Value added & FR \\
\hline & Value added per unit value of sales & FR \\
\hline & Value added per direct employee & FR \\
\hline & Gross margin per direct employee & FR \\
\hline & Return on average capital employed & FR \\
\hline & Taxes paid, as percent of NIBT & FR \\
\hline Investments & Percentage increase (decrease) in capital employed & FR \\
\hline & R\&D expenditure as \% sales & FR \\
\hline & Employees with post-school qualification & (?) \\
\hline & New appointments/number of direct employees & FR (?) \\
\hline & Training expense as percentage of payroll expense & (?) \\
\hline & Ratio of indirect jobs/number of direct employees & (?) \\
\hline & Investment in education/employee training expense & (?) \\
\hline & Charitable gifts as percentage of NIBT & FR \\
\hline Additional economic items & & \\
\hline & & \\
\hline
\end{tabular}

\begin{tabular}{|l|l|l|}
\hline Social indicators & & LR Source \\
\hline Workplace & & \\
\hline Employment situation & Benefits as percentage of payroll expense & FR \\
\hline & $\begin{array}{l}\text { Employee turnover (resigned + redundant/number } \\
\text { employed) }\end{array}$ & FR (?) \\
\hline & Promotion rate (number of promotions/number employed) & (?) \\
\hline & Working hours lost as percent of total hours worked & FR \\
\hline & Income + benefit ratio (top 10\%/bottom 10\%) & (?) \\
\hline $\begin{array}{r}\text { Health and safety at } \\
\text { work }\end{array}$ & $\begin{array}{l}\text { Lost time accident frequency (number per million hours } \\
\text { worked) }\end{array}$ & AR / FR \\
\hline $\begin{array}{l}\text { Society } \\
\text { expenditure on illness and accident prevention/payroll }\end{array}$ & FR (?) \\
\hline & $\begin{array}{l}\text { Number of stakeholder meetings per unit value added } \\
\text { Indirect community benefit per unit value added }\end{array}$ & $\begin{array}{l}\text { AR / FR / SMP } \\
\text { (?) }\end{array}$ \\
\hline & Number of complaints per unit value added & SIA / SMP (?) \\
\hline & Number of legal actions per unit value added & (?) \\
\hline Additional social items & & \\
\hline
\end{tabular}

